\title{
The Role of Belt Wall in Minimizing The Response Due To Wind Load
}

\author{
Roslida Abd. Samat ${ }^{1, *}$, Nasly Mohamed Ali ${ }^{2}$, Abdul Kadir Marsono ${ }^{1}$, and Abu Bakar Fadzil ${ }^{1}$ \\ ${ }^{1}$ Faculty of Civil Engineering, Universiti Teknologi Malaysia, 81310 Skudai, Johor, Malaysia \\ ${ }^{2}$ Faculty Of Civil Engineering \& Earth Resources, Universiti Malaysia Pahang, 26600 Pekan, Pahang, Malaysia
}

\begin{abstract}
Outrigger is one of the tall building structural systems that are used to reduce the building responses due to the wind. Outrigger is a stiff beam that connects the core wall to exterior columns and this enables the vertical shear to be transferred from the core to the external columns, thereby forcing the perimeter columns to participate in carrying the overturning moment due to the wind. Belt wall is often added to a building with outrigger system to further reduce the displacement and acceleration of a tall building having an outrigger system. However, it is not known how effective the belt wall is in further reducing the building responses. Thus, 64 story reinforced concrete buildings are studied in order to determine how the belt wall improves the building responses due to the wind. Buildings with an outrigger system and buildings with a combination of the outrigger and belt wall system are analysed by a structural engineering software in order to determine the natural frequencies and eigenvectors in the along-wind, across-wind and torsional direction. The along-wind responses are determined by employing the procedures from the ASCE 7-16 while the across-wind responses of the buildings are calculated based on the procedures and wind tunnel data available in a database of aerodynamic load. Results from the analysis show that the belt wall reduces the along-wind and across-wind responses slightly. However, belt wall reduces the torsional acceleration of the buildings significantly, which otherwise cannot be reduced by the outrigger system.
\end{abstract}

\section{Introduction}

Deflection and acceleration of tall buildings must be controlled as large deflection and high acceleration may cause discomfort to the building occupants. Deflection of more than $1 / 200$ of the height of the buildings, for example, can result in improper drainage, impaired operation of doors and windows, and damage to lightweight partition [1]. Thus, the deflection cannot exceed a certain limit that has been specified by the local building authorities. The limit of drift index, which is the ratio of the maximum deflection at the top of the building to the total height is between 0.001 to 0.005 for different countries. The maximum total drift and interstory drift of structure that is subjected to wind force allowed by Malaysian Code, MS 1553:2002 [2], is 1/500 and $1 / 750$ of the height, respectively. Further, [3] recommended the drift limits of building to be between $1 / 600$ to $1 / 400$.

According to [4], human perception to motion and vibration is affected mainly due to acceleration. People can strongly perceive motion and have difficulty in walking naturally as well as losing balance while standing if the acceleration exceeds $0.4 \mathrm{~m} / \mathrm{s} 2$ [5]. ASCE7-16 [6] specifies the need to control the structural motion by reducing both building and floor accelerations such that the discomfort of the occupants and the impairment of the equipment could be avoided. People in a quiet environment will be disrupted when the acceleration of nonstop vibrations is between $0.05 \mathrm{~g}$ to $0.01 \mathrm{~g}$ but those in a loud environment such as during events will be irritated only when the acceleration reaches $0.02 \mathrm{~g}$ to $0.05 \mathrm{~g}$. Further, peak acceleration influences the perception of motion while comfort during continuous motion is related to RMS acceleration [7]. The occupant comfort in the building can also be evaluated based on the modal acceleration [8]. According to [9], the current design code of practice that applies perception threshold has failed to include other significant effects due to building motion such as sopite syndrome and work performance.

The structural response of the building can be reduced by employing alternative structural systems or passive and active control devices [10]. Belt wall and outriggers systems are tall building structural systems that can be employed to minimize the building responses caused by wind. An outrigger is a stiff beam that connects the core of high rise building to the peripheral columns. The existence of outrigger causes the emergence of tensile forces in the columns at the windward surface and compressive forces in the columns at the leeward surface when the building is subjected to lateral load [11]. According to [12], outriggers improves the building overturning stiffness and strength. Multiple

\footnotetext{
* Corresponding author: author@e-e-mail.org
} 
outriggers can be constructed in building. [13] studied the effect of using four outriggers that were located at different height from the ground in reducing the lateral displacement due to the wind.

Belt wall is added to building with outrigger to mobilize the other peripheral columns other than those columns located at the ends of the outriggers in resisting the lateral load. Belt wall is a deep spandrel beam which can be either one or two stories that are constructed around the building at the same level as the outriggers. The 77-story Plaza Rakyat Office Tower in Kuala Lumpur, Malaysia utilizes core wall, perimeter frame, two belt walls and three outriggers to resist wind load [14]. Tower Palace III in Seoul Korea employs indirect outrigger belt wall system to control wind-induced response [15].

However, it is not known how effective the belt wall is in reducing further the responses of buildings with outrigger system. The objective of this research is to study the effectiveness of belt wall system in minimizing the building response (displacement and acceleration) to wind loading.

\section{Properties of Building Models}

Analysis was performed on a reinforced concrete building with a footprint of $48 \mathrm{~m} \mathrm{x} 48 \mathrm{~m}$ square plan. The $288 \mathrm{~m}$ high building has 64 stories and is categorized as a flexible building due to the ratio of height to the horizontal dimension of the building exceeding 4:1 and its lowest natural frequency being less than $1 \mathrm{~Hz}$. Fig. 1 shows the typical plan of the building investigated.

The reinforced concrete core, columns, diagonal beams and perimeter beams used high strength concrete with strength of $80 \mathrm{MPa}$ and modulus of elasticity $4.83 \mathrm{x}$ $107 \mathrm{kPa}$. The $110 \mathrm{~mm}$ thick composite floor was supported by wide flange beams with section of UB 457 x $191 @ 98$ kg/m, UB 610 x $229 @ 125$ kg/m UB 610 X $305 @ 179 \mathrm{~kg} / \mathrm{m}$ for core wall size of $12 \mathrm{~m} x 12 \mathrm{~m}, 18 \mathrm{~m} \mathrm{x}$ $18 \mathrm{~m}$ and $24 \mathrm{~m} \times 24 \mathrm{~m}$, respectively, that span from the core wall to the perimeter beams.

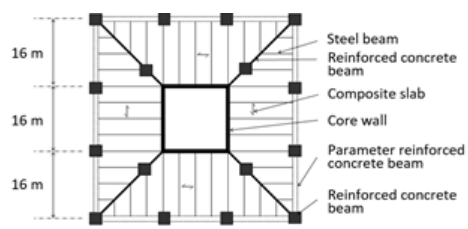

Fig. 1. Typical plan view of the building investigated.

Two thicknesses of core wall, which were $350 \mathrm{~mm}$ and $800 \mathrm{~mm}$ were used for each size of the core wall. The thickness of the core wall was constant throughout the height of the building. The internal columns which exist only in buildings with $12 \mathrm{~m} \times 12 \mathrm{~m}$ and $18 \mathrm{~m} \mathrm{x} 18$ $\mathrm{m}$ core wall had cross sections of $1300 \mathrm{~mm} \times 1300 \mathrm{~mm}$, $1100 \mathrm{~mm} \times 1100 \mathrm{~mm}$ and $700 \mathrm{~mm} \times 700 \mathrm{~mm}$ for floor 1 to 25,26 to 50 and 51 to 64 respectively. The perimeter and diagonal beams had $300 \mathrm{~mm}$ x $1000 \mathrm{~mm}$ crosssection.
Three types of buildings were investigated: core wall, combination of core wall and outriggers and combination of core wall, outriggers and belt wall. Buildings with outriggers had four $400 \mathrm{~mm}$ wide and two-storey high outriggers that connected the corner of the core wall to the peripheral columns at the corner of the building at mid-height of the buildings. The belt wall used in this study was solid $350 \mathrm{~mm}$ wide and two storeys high reinforced concrete wall. white, and this should be taken into account when preparing them.

\section{Methodology}

The procedure of this project is as given below:

1. Model the building and analyse it by using the structural analysis and design software, GTSTRUDL in order to obtain the eigenvalues and eigenvectors of the building corresponding to along wind, across wind and torsional modes.

2. Compute the responses in the along wind direction by employing the equation given by the ASCE 7-16. Data such as the dimensions, frequency and mass of the building; wind speed and type of terrain are required to execute the along-wind response.

3. Execute the across wind and torsional responses. The value of $\mathrm{CM}$, non-dimensional moment coefficient and $\sigma_{M}$, root mean square of the fluctuating base moment was obtained from an interactive aerodynamic database of the University of Notre Dame, U.S.A. columns at the top or the bottom of the page.

\subsection{Modeling of the Building}

Space frame members were used to model all columns and beams. Meanwhile, isoparametric quadratic solid (IPQS) elements that have 20 nodes each, were used to model the core walls, outriggers and belt walls. Each node of the IPQS element has three degrees of freedom, which are displacements: u1, u2, u3, Fig.2 shows the models of outrigger building system and combination of belt wall and outrigger system used for the eigenproblem analysis which was performed by GTSTRUDL structural analysis software to obtain the natural frequency in the along-wind, across-wind, and torsional directions, as well as the eigenvectors in the across-wind direction. 


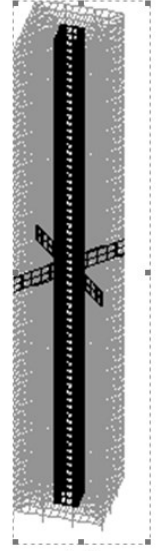

(a)

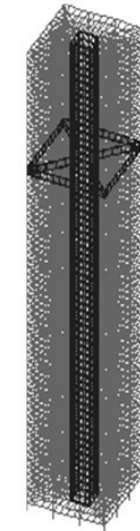

(b)
Fig. 2. (a) Outrigger and core wall system; (b) Beltwall, outrigger and core wall system

\subsection{Wind Speed}

Wind speeds in three wind environment: Malaysia, New York and Hong Kong were used in this investigation. Malaysia which experiences thunderstorms and monsoonal winds has benign wind environment. Both New York and Hong Kong have aggressive wind environment. New York is exposed to hurricane whilst Hong Kong is exposed to typhoon. The 3 -second gust wind speed for 50 year return period at $10 \mathrm{~m}$ height is $33.5 \mathrm{~m} / \mathrm{s}$ (MS 1553:2002) in Kuala Lumpur and $49 \mathrm{~m} / \mathrm{s}$ in New York (ASCE 7-16). Hong Kong has 3-second gust wind speed for 50 year return period of $68 \mathrm{~m} / \mathrm{s}$ at $50 \mathrm{~m}$ height (Hong Kong Code of Practice) [16].

Along-wind responses were determined by utilizing the formulation given in ASCE 7-16 where 3-second gust wind speeds for 10 -year return period at $10 \mathrm{~m}$ height in open terrain was used. The 3 -second gust wind speeds for 10-year return period at $10 \mathrm{~m}$ height in open terrain for Malaysia, New York and Hong Kong wind environment were $28.14 \mathrm{~m} / \mathrm{s}, 36.26 \mathrm{~m} / \mathrm{s}$ and $42.48 \mathrm{~m} / \mathrm{s}$, respectively. Meanwhile, one-hour averaging time wind speeds for 10-year return period at building height in urban area was used in the calculation of the across-wind and torsional responses which utilized the procedure outlined in the aerodynamic database in the University of Notre Dame. The 3-second gust wind speed at $10 \mathrm{~m}$ height was converted to the wind speed at the building height by using the power law and then was converted to one-hour averaging time by using the curve given in ASCE7-16. The wind speeds were $25.27 \mathrm{~m} / \mathrm{s}, 32.56 \mathrm{~m} / \mathrm{s}$ and $38.14 \mathrm{~m} / \mathrm{s}$ for Malaysia, New York and Hong Kong wind environment, respectively.

\subsection{Along-Wind Response Positioning}

The natural frequency and the wind speed were needed to calculate the along-wind displacement and acceleration by employing closed form equation provided in the ASCE7-16. The maximum along-wind displacement $X \max (z)$ as a function of height above the ground surface is given by

$$
X_{\max }(z)=\frac{\phi(z) \rho b h C_{f} \hat{V}_{\bar{Z}}^{2}}{2 m_{1}\left(2 \pi n_{1}\right)^{2}} K G
$$

where $\phi(z)=$ fundamental mode shape $=(z \mid h)^{\xi} ; \xi=$ mode exponent; $\rho=$ the air density; $C_{f}=$ mean alongwind force coefficient; $m_{1}=$ modal mass $=\int \mu(z) \phi^{2}(z) d z$ ; $m_{1} \mu(z)=$ mass per unit height; $K=1.65 \hat{\alpha} /(\hat{\alpha}+\xi+1) ; \hat{V}_{\bar{z}}=$ the $3 \mathrm{sec}$ gust speed at height $\bar{z}=\hat{b}(z / 33)^{\hat{\alpha}} \hat{V}_{\text {ref }}, \hat{V}_{\text {ref }}=3 \mathrm{~s}$ gust in exposure $\mathrm{C}$ at reference height; $G_{f}=$ gust factor; $n_{1}=$ building natural frequency in $\mathrm{Hz}$. The maximum along-wind acceleration as a function of height above the ground surface is given by

$$
\begin{aligned}
& \ddot{X}_{\text {max }}(z)=g_{\ddot{x}} \sigma_{\ddot{x}}(z) \\
& \text { where } \sigma_{\ddot{x}}(z)=\text { rms along-wind acceleration as a } \\
& \text { function of height above the ground surface; } \\
& g_{\ddot{x}}=\sqrt{2 \ln \left(n_{1} T\right)}+\frac{0.5772}{\sqrt{2 \ln \left(n_{1} T\right)}} \text { and } T=3600 \text { seconds }
\end{aligned}
$$

\subsection{Across-Wind and Response}

Both of the across-wind and torsional responses computed in this project were based on the aerodynamic database of the University of Notre Dame that can be accessed at the URL address http://www.nd.edu/ nathaz/. The database stores the non-dimensional moment coefficient, $\mathrm{CM}$ which was calculated based on the results from the wind tunnel test of different models. The models had different cross sections which were rectangular with different width to depth ratio, triangular and parallelogram. Three different heights $(406 \mathrm{~mm}, 508 \mathrm{~mm}$ and $610 \mathrm{~mm}$ ) for each type of cross section were used. These rigid balsa wood models were tested in an $18 \mathrm{~m}$ long boundary layer wind tunnel with a $3 \mathrm{~m} \times 1.5 \mathrm{~m}$ cross-section [17]. The upstream spires together with the surface roughness that was added to the tunnel floor create the required boundary layers in the wind tunnel. The dynamic structural loads of models due to the wind in boundary layers of open terrain and urban area were determined by using a highfrequency multicomponent force balance [18] Measurement was made at a rate of $300 \mathrm{~Hz}$ for a 5minute duration. Fast Fourier transform was applied to obtain the spectra which were ensemble averaged.

The calculation of torsional acceleration requires the values of the radius of gyration of the building while the computation of the across-wind displacement requires eigenvectors and lumped mass at selected points. Only the maximum across-wind and torsional acceleration which occur at the top of the building, are computed. white, and this should be taken into account when preparing them.

\section{Results And Discussion}

The results from the analysis show that the reduction of the along-wind responses due to the addition of the belt wall to a building which already has an outrigger system 
is less than the reduction of the along-wind response when the outriggers system is added to a building which has no outrigger at all (Fig. 3 and 4). The reduction of the across-wind responses due to the wind in all the three wind environment: Malaysia, New York and Hong Kong when belt walls are added to the buildings with the outrigger system is less than the reduction of the acrosswind responses when the outrigger system is added to a building which has no outrigger at all. Fig. 5 plots the histograms of the across-wind responses that correspond to Hong Kong wind environment.

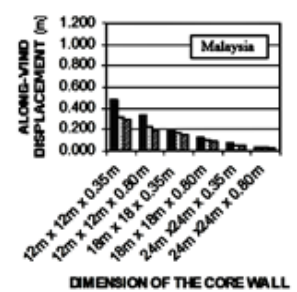

(a)

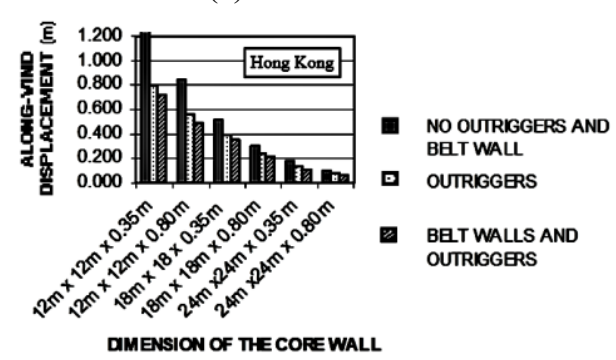

(c)

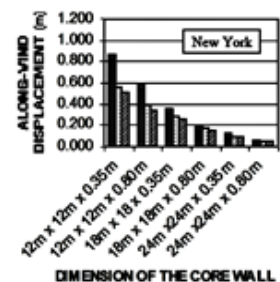

(b)
Fig. 3. Comparison of the value of the along-wind displacement for a building with two-storey deep outriggers and a building with both two-storey deep outriggers and belt walls in (a) Malaysia, (b) New York and, (c) Hong Kong wind environment.

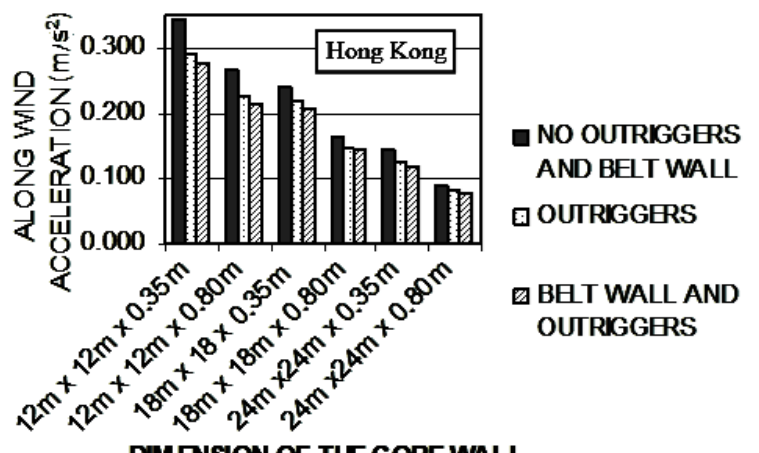

Fig. 4 Comparison of the along-wind acceleration of a building with two-storey deep outriggers and a building with both twostorey deep outriggers and belt walls in Hong Kong wind environment.

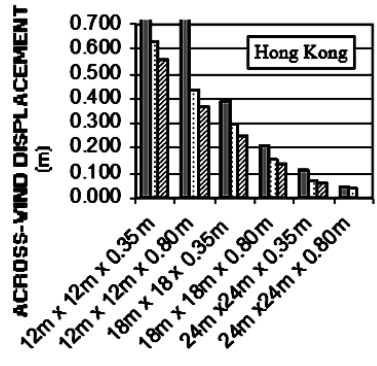

DMENSION OF THE CORE WALL

NO OUTRIGGER AND BELT WALI

(a)

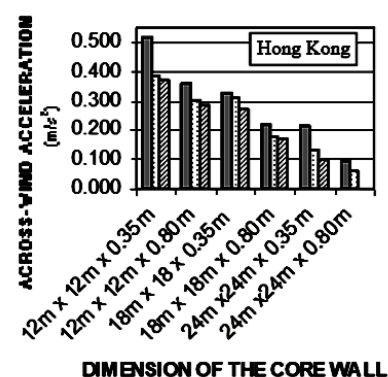

DIMENSION OF THE CORE WALL
BELT WALL AND

(b)

Fig. 5 Comparison of the (a) across-wind displacement (b) across-wind acceleration of a building with no outriggers, twostorey deep outriggers and with both two-storey deep outriggers and belt walls in Hong Kong wind environment.

Interestingly, the torsional response of the building remained the same when the outriggers system was added to the building. However, when belt wall was added to a building with outrigger system, the torsional response of the building reduced significantly as shown in Fig. 6. This is due to the increment of the natural frequency in the torsional mode which was caused by the increment of the torsional stiffness of the building due to the addition of the belt wall. Table 1 tabulates the values of torsional stiffness constant, $K$, for the core wall, outrigger and belt wall. The $K$ value is the same for all belt walls as the dimension of the belt wall is the same for all the buildings no matter what the dimension of the core wall is (Fig. 7). Table 1 also shows the value of the natural frequency for the building with core wall and a combination of outriggers and core wall is the same for the torsional mode due to the small contribution of the $K$ values by the outriggers to the original building with core wall only. On the other hand, the sudden increment of the natural frequency in the torsional mode due to the addition of the belt wall is caused by the large value of $K$ of the belt wall that was added to the original building system

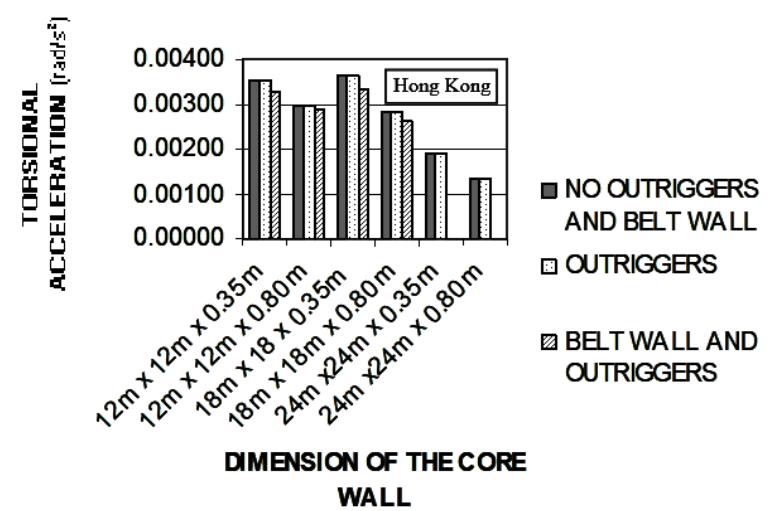

Fig. 6. Comparison of the value of the torsional acceleration of a building with no outriggers, two-storey deep outriggers and a building with both two-storey deep outriggers and belt walls in Hong Kong wind environment. 
Table 1. Comparison of the $K$ or torsional stiffness constant values of the core wall, outrigger and belt wall elements, and the natural frequency in torsional mode of the building with belt wall and no belt wall.

\begin{tabular}{|c|c|c|c|c|c|c|}
\hline \multirow{2}{*}{$\begin{array}{c}\frac{\text { CORE WALL }}{\text { SIZE }} \\
(\mathrm{M} \times \mathrm{M} \times \mathrm{MM})\end{array}$} & \multirow{2}{*}{$\begin{array}{c}\text { K VALUES } \\
\text { OF THE } \\
\text { CORE } \\
\text { WALL } \\
\text { (NM) }\end{array}$} & \multirow{2}{*}{$\begin{array}{c}\text { KVALUES } \\
\text { OOF TIEE } \\
\text { OUTRIGGER } \\
\text { (NM) }\end{array}$} & \multirow{2}{*}{$\begin{array}{c}\text { KVALUES } \\
\text { OF THE } \\
\text { BELT } \\
\text { WALL } \\
\text { (NM) }\end{array}$} & \multicolumn{3}{|c|}{$\begin{array}{l}\text { NATURAL FREQUENCY } \\
\text { IN TORSIONAL MODE }\end{array}$} \\
\hline & & & & $\begin{array}{l}\text { BULDING WTIH } \\
\text { CORE WALL } \\
\text { ONLY } \\
\text { (HZ) }\end{array}$ & $\begin{array}{c}\text { BUILDING WITH } \\
\text { CORE WALI, } \\
\text { OUTRIGGER } \\
\text { (HZ) }\end{array}$ & $\begin{array}{l}\text { BUIDING WITH } \\
\text { CORE WALI, } \\
\text { OUTRGGER } \\
\text { AND BELT } \\
\text { WALL } \\
\text { (HZ) }\end{array}$ \\
\hline $\begin{array}{c}12 \times 12 \times \\
0.35\end{array}$ & 553.408 & 34.412 & 38225.37 & 0.145 & 0.145 & 0.170 \\
\hline $\begin{array}{c}18 \times 18 \times \\
0.35\end{array}$ & 1924.430 & 28.619 & 38225.37 & 0.173 & 0.173 & 0.192 \\
\hline $\begin{array}{c}24 \times 24 \times \\
0.35\end{array}$ & 4629.792 & 22.826 & 38225.37 & 0.281 & 0.281 & 0.309 \\
\hline
\end{tabular}

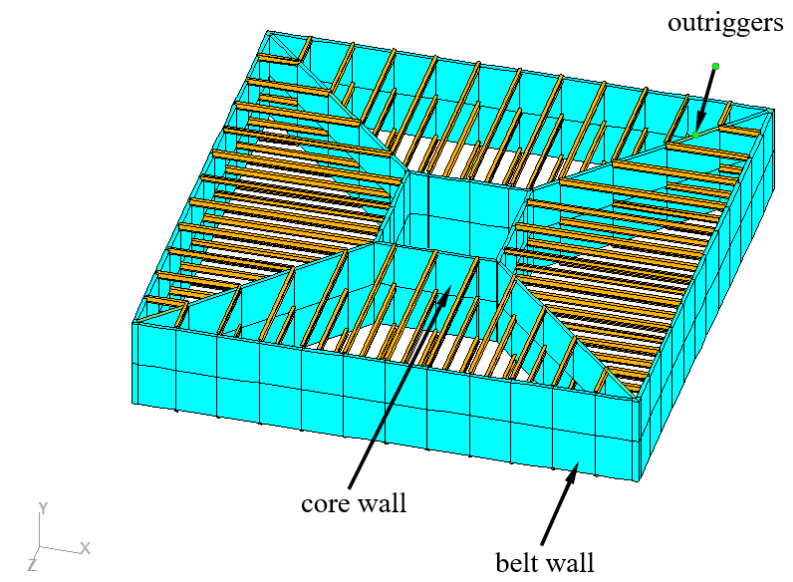

Fig. 7 A view of a floor where the belt wall is located.

\section{Conclusion}

The purpose of conducting the study on the belt wall system is to find out how the addition of the belt walls improves the responses of a building which already built with the outrigger system. The addition of belt walls to a building that already has the outrigger system will reduce slightly the responses in the along-wind and across-wind direction. In contrast, the torsional acceleration which otherwise could not be reduced when only the outriggers are added to the core wall system is reduced significantly when the belt wall is added to the buildings with the outrigger system. As a conclusion, belt wall is effective in reducing the torsional acceleration but is not so effective in reducing the alongwind and across-wind responses.

Furthermore, allowing perforation of the belt wall will allow the floor where belt wall is located for usage other than as a mechanical floor as commonly practiced. Thus, it is suggested that a study of buildings that have belt wall system with perforation to be performed in order to understand its effectiveness in reducing the building responses due to the wind.

\section{References}

1. T. Balendra, T. Vibration of Buildings to Wind and Earthquake Loads ( 1993)
Table 1. Setting Word's margins.

\begin{tabular}{|c|c|}
\hline Margin & $\mathbf{m m}$ \\
\hline Top & 25 \\
\hline Bottom & 20 \\
\hline Left & 20 \\
\hline Right & 20 \\
\hline
\end{tabular}

Use a two-column format, and set the spacing between the columns at $8 \mathrm{~mm}$. Do not add any page numbers.

\subsection{Formatting the title, authors and affiliations}

\subsubsection{Formatting the title}

The title is set in bold 16-point Arial, justified. The first letter of the title should be capitalised with the rest in lower case. You should leave $35 \mathrm{~mm}$ of space above the title and $6 \mathrm{~mm}$ after the title.

\subsubsection{Formatting author names and author affiliations}

The style for the names is First Name, typed in italic 10point Times, then Last Name, typed in 10-point Times, with a comma after all except the last author, which is separated by comma + "and". Do not use academic titles.

Affiliations of authors should be typed in 9-point Times. They should be preceded by a numerical superscript corresponding to the same superscript after the name of the author concerned. Please ensure that affiliations are as full and complete as possible and include the country.

\subsection{Formatting the text}

The text of your paper should be formatted as follows:

- 10-point Times, Times Roman or Times New Roman.

- The text should be set to single line spacing.

- Paragraphs should be justified.

- The first paragraph after a section or subsection should not be indented; subsequent paragraphs should be indented by $5 \mathrm{~mm}$.

The use of sections to divide the text of the paper is optional and left as a decision for the author. Where the author wishes to divide the paper into sections the formatting shown in Table 2 should be used. 
Table 2. Formatting sections, subsections and subsubsections.

\begin{tabular}{|c|c|c|c|}
\hline & Font & Spacing & numbering \\
\hline Section & $\begin{array}{c}\text { 12-point } \\
\text { Arial bold }\end{array}$ & $\begin{array}{c}6 \mathrm{~mm} \text { before } \\
3 \mathrm{~mm} \text { after }\end{array}$ & $1,2,3$, etc. \\
\hline subsection & $\begin{array}{c}10 \text {-point } \\
\text { Arial bold }\end{array}$ & $\begin{array}{c}6 \mathrm{~mm} \text { before } \\
3 \mathrm{~mm} \text { after }\end{array}$ & $\begin{array}{c}1.1,1.2,1.3, \\
\text { etc. }\end{array}$ \\
\hline subsubsection & $\begin{array}{c}10 \text {-point } \\
\text { Arial Italic }\end{array}$ & $\begin{array}{c}6 \mathrm{~mm} \text { before } \\
3 \mathrm{~mm} \text { after }\end{array}$ & $\begin{array}{c}1.1 .1,1.1 .2, \\
1.1 .3, \text { etc. }\end{array}$ \\
\hline
\end{tabular}

\section{Figures and tables}

Figures and tables, as originals of good quality and well contrasted, are to be in their final form, ready for reproduction, pasted in the appropriate place in the text. Try to ensure that the size of the text in your figures is approximately the same size as the main text (10 points). Try to ensure that lines are no thinner than 0.25 point.

Fig. 1. Caption of the Figure 1. Below the figure.

\subsection{Captions/numbering}

Captions should be typed in 9-point Times. They should be centred above the tables and flush left beneath the figures.

\subsection{Positioning}

Place the figure as close as possible after the point where it is first referenced in the text. If there is a large number of figures and tables it might be necessary to place some before their text citation. If a figure or table is too large to fit into one column, it can be centred across both columns at the top or the bottom of the page.

\subsection{Colour illustrations}

You are free to use colour illustrations for the online version of the proceedings but any print version will be printed in black and white unless special arrangements have been made with the conference organiser. Please check with the conference organiser whether or not this is the case. If the print version will be black and white only, you should check your figure captions carefully and remove any reference to colour in the illustration and text. In addition, some colour figures will degrade or suffer a loss of information when converted to black and white, and this should be taken into account when preparing them.

\section{Equations and mathematics}

Equations should be centred and should be numbered with the number on the right-hand side.

$$
\begin{gathered}
T_{\mathrm{s}}(l, t)=T_{\mathrm{g}}(l, t) \\
T_{\mathrm{s}}(l, t)=T_{\mathrm{g}}(l, t) T_{\mathrm{b}}(x \rightarrow-\beta, t)=0
\end{gathered}
$$

Use italics for variables $(u)$ and bold (u) for vectors. The order for brackets should be $\{[()]\}$, except where brackets have special significance.

The acknowledgements should be typed in 9-point Times, without title.

\section{References}

Online references will be linked to their original source, only if possible. To enable this linking extra care should be taken when preparing reference lists.

References should be cited in the text by placing sequential numbers in brackets (for example, [1], [2, 5, 7], [8-10]). They should be numbered in the order in which they are cited. A complete reference should provide enough information to locate the article. References to printed journal articles should typically contain:

- The authors, in the form: initials of the first names followed by last name (only the first letter capitalized with full stops after the initials),

- The journal title (abbreviated),

- The volume number (bold type),

- The article number or the page numbers,

- The year of publication (in brackets).

Authors should use the forms shown in Table 3 in the final reference list.

Table 3. Font styles for a reference to a journal article.

\begin{tabular}{|c|c|}
\hline Element & Style \\
\hline Authors & $\begin{array}{c}\text { Normal } \\
\text { Initials followed by last name }\end{array}$ \\
\hline Journal title & $\begin{array}{c}\text { Normal } \\
\text { Abbreviated }\end{array}$ \\
\hline $\begin{array}{c}\text { Book title, } \\
\text { Proceedings title }\end{array}$ & Italic \\
\hline Volume number & Bold \\
\hline Page number & Normal \\
\hline Year & $\begin{array}{c}\text { Normal } \\
\text { In brackets }\end{array}$ \\
\hline
\end{tabular}

Here are some examples:

1. A. Mecke, I. Lee, J.R. Baker jr., M.M. Banaszak Holl, B.G. Orr, Eur. Phys. J. E 14, 7 (2004)

2. M. Ben Rabha, M.F. Boujmil, M. Saadoun, B. Bessaïs, Eur. Phys. J. Appl. Phys. (to be published)

3. Luigi T. De Luca, Propulsion physics (EDP Sciences, Les Ulis, 2009)

4. F. De Lillo, F. Cecconi, G. Lacorata, A. Vulpiani, EPL, 84 (2008)

5. Malaysian Standard on Code of Practice on Wind Loading for Building Structure, MS 1553:2002 (2002) 
6. ASCE Task Committee on Drift Control of Steel Building Structures. J. Struct. Div., ASCE 114(9), 2085-2108 (1988)

6. A.W. Irwin, Proc. Conf. On Tall Buildings. Second Century of the Skyscraper, 759-778 (1986)

7. M. Yamada, T. Goto, Proc. Pan-Pacific Tall Buildings Conference, 233-244. (1975)

8. American Society of Civil Engineers Minimum Design Loads for Buildings and Other Structures, New York, ASCE 7-16 (2016)

9. F.A. Johann, M.E.N. Carlos, F.L.S. Ricardo. J. Wind Eng. Ind. Aerodyn, 142, 26-42 (2015)

10. F.Jiyang, Q. Zheng, Y. Huang, J.Wu, Y.Pi, Q. Liu. Eng. Struct, 156 460-47 (2018)

11. S.Lamb, V.G. Macefield, D. K. Walton and K.C.S. Kwok, Proc. of the Inst. of Civil Eng. (2016)

12. 10 A. Kareem, T. Kijewski, and Y. Tamura, Wind Struct. 2(3), 201-251 (1999)

13. 11. B.S. Smith and A. Coull, Tall Building Structures : Analysis and Design. (1991)

14. V. Dongre and V. Garg. Int Research J of Eng and Technol (IRJET) 5 Issue 1. (2018)

15. Prajyot A. Kakde, Ravindra Desai. Int Research J of Eng and Technol (IRJET) 4 (2017)

16. W.F.Baker, C.D.Brown, R.C. Sinn, Struct Eng World Wide. T114-3 (1998)

17. A. Abdelrazaq, T. Kijewski, Y. H.Song, P.Case, N. Isyumov, A. Kareem. Proc of 6th Asia-Pacific Conf on Wind Eng, APCWE (2005)

18. Building Authority, Hong Kong. Code of Practice on Wind Effects Hong Kong. (1983)

19. A. Kareem, A.J Wind Eng Ind Aerod. 36, 589-599 (1990)

20. Y. Zhou, T. Kijewski A., Kareem. J of Struct Eng. 129(3), 394-404 (2003) 